\title{
Collagenases in Human Synovial Fluid
}

\author{
Edward D. Harris, Jr., Donald R. DiBona, and Stephen M. Krane \\ From the Department of Medicine, Harvard Medical School, and the Medical \\ Services, Massachusetts General Hospital, Boston, Massachusetts 02114
}

A в S T RACT An enzyme which degrades native collagen at neutral $\mathrm{pH}$ has been isolated from cultures of rheumatoid synovium in vitro, but little or no collagenolytic activity has been found in homogenates of fresh rheumatoid synovium. Similar to most other mammalian collagenases this synovial enzyme is readily inhibited by serum proteins. Proteins of synovial fluid are derived largely from serum and synovial fluid from noninflamed joints was found to inhibit synovial collagenase; the inhibitor was destroyed by trypsin, but not by hyaluronidase. Inhibitory activity was reduced in approximately one-half of the fluids from patients with rheumatoid arthritis. In a total of nine synovial fluids, collagenolytic activity was detectable. This activity was not present in constant amounts in synovial fluids aspirated at different times from the same patient and tended to vary inversely with the titer of inhibitory proteins. The collagenolytic activity in the synovial fluids from different patients was variably inhibited by serum proteins. Two distinct collagenases were detected in some rheumatoid synovial fluids and separated by gel filtration. One, labeled "B" enzyme, with an estimated molecular weight 20,000-25.000 resembled the collagenase obtained from synovial cultures. The other, labeled " $\mathrm{A}$ " enzyme with an estimated molecular weight of $40,000-50,000$. was not inhibited by serum. Unlike the leukocytic collagenase, however, the " $\mathrm{A}$ " enzyme degraded collagen fibrils as well as collagen in solution. Disc electrophoresis on acrylamide gels and electron microscopy of segment long spacing (SLS) aggregates of reaction products of the enzymes at $27^{\circ} \mathrm{C}$ demonstrated that both " $\mathrm{A}$ " and " $\mathrm{B}$ " enzymes cleaved collagen molecules at a point three-quarters from the amino terminal end of the molecule. Thus collagen degradation in rheumatoid arthritis could result from the operation of these two collagenases.

This is publication No. 482 of the Robert W. Lovett Memorial Group for the Study of Diseases Causing Deformities.

Dr. Harris was a Special Postdoctoral Fellow of the National Institutes of Arthritis and Metabolic Diseases.

Received for publication 20 May 1969.

\section{INTRODUCTION}

An enzyme capable of degrading native, undenatured collagen at neutral $\mathrm{pH}$ has been detected in the medium from organ cultures of rheumatoid synovium (1-4). The properties of this collagenase are similar to those of an enzyme obtained from cultures of normal human skin (5) and to that from cultures of several tissues from the metamorphosing tadpole (6). Crude and partially purified preparations of these enzymes are readily inhibited by serum proteins. Furthermore, no collagenase has been found in homogenates of these tissues whereas homogenates of human granulocytes have been shown to contain detectable collagenase $(7,8)$. In order to establish a role for these tissue collagenases in the remodelling or destruction of collagenous tissues it is necessary to demonstrate that enzyme(s) with similar properties to that released in vitro is produced in vivo at levels sufficient to overcome the inhibition by serum proteins or in a form which is not inhibitable by serum.

Synovial fluid is formed by the exudation of proteinrich fluid from subsynovial capillaries and by the addition of proteins and proteinpolysaccharides synthesized by the synovial lining cells. It seemed possible that in rheumatoid arthritis, enough collagenase might be released into some synovial fluids from cells such as the synovial cells to be detected despite the presence of the serum proteins. In the present study such collagenolytic activity has been measured in synovial fluids from several patients with rheumatoid arthritis. This activity has been shown to consist of two collagenases of different molecular size and of different susceptibility to inhibition by serum proteins.

\section{METHODS}

Patients. Rheumatoid synovium was obtained from patients with rheumatoid arthritis undergoing synovectomy of the knee. Synovial fluid was aspirated from patients with knee effusions, centrifuged at $4^{\circ} \mathrm{C}$, stored in sterile containers, and frozen until assayed.

Collagenase assays. Guinea pig skin collagen unlabeled or labeled with I-glycine $-{ }^{-14} \mathrm{C}$ was prepared as described previously (1-3). Specific activity of the radioactive collagen 


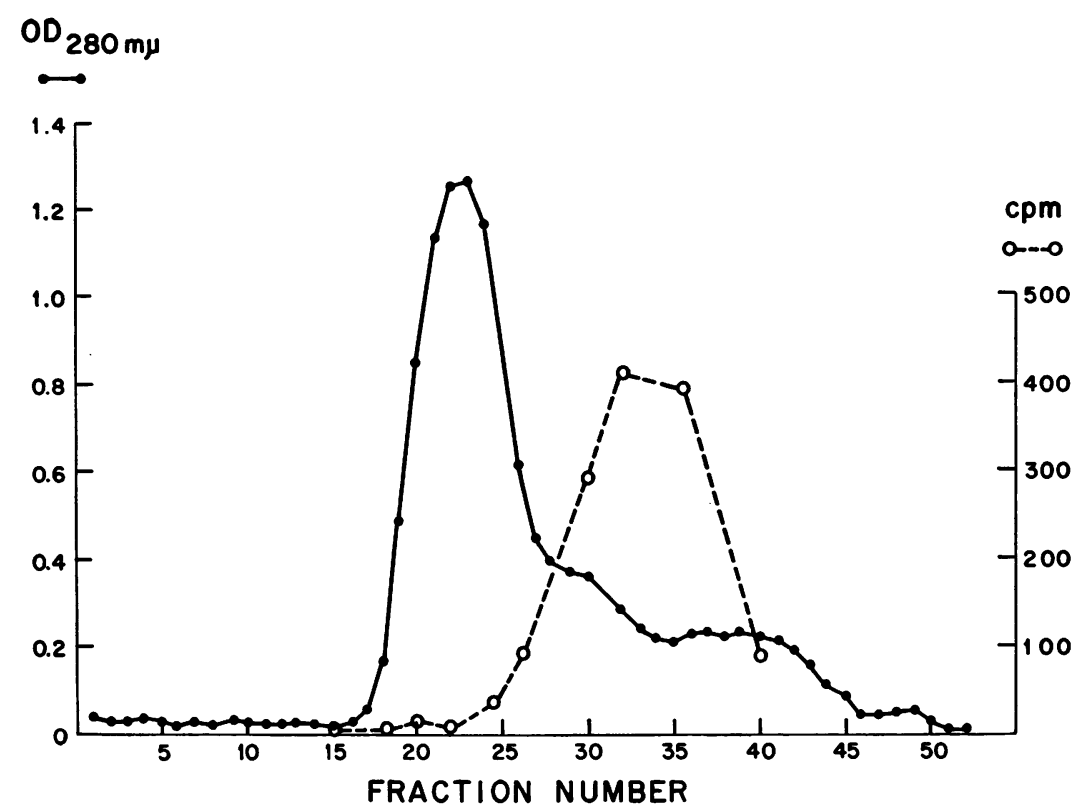

FIGURE 1 Gel filtration of cultured synovial collagenase. A Sephadex G-200 column $(112 \times 0.9 \mathrm{~cm})$ was equilibrated with $0.1 \mathrm{M}$ Tris- $\mathrm{HCl}, \mathrm{pH} 7.6,0.005 \mathrm{M}$ $\mathrm{CaCl}_{2}, 0.2 \mathrm{M} \mathrm{NaCl}$ at $4^{\circ} \mathrm{C}$. The sample applied to the column was concentrated media from days 4 and 5 of culture of rheumatoid synovium. Fractions containing $2.1 \mathrm{ml}$ were collected. Optical density (solid line) was determined at $280 \mathrm{~m} \mu$. Collagenase assay (broken line) was performed using $100 \mu \mathrm{l}$ samples of selected fractions in the system described in Table I.

was approximately $30,000 \mathrm{cpm} / \mathrm{mg}$. Collagen gels were prepared by incubating $50 \mu \mathrm{l}$ of a $0.05 \%$ solution of collagen in $0.1 \mathrm{M}$ Tris- $\mathrm{HCl}, \mathrm{pH} 7.6,0.005 \mathrm{M} \mathrm{CaCi}_{2}$ at $37^{\circ} \mathrm{C}$ in small plastic tubes. The period of incubation in the assay of selected enzymes and synovial fluids was $2-6 \mathrm{hr}$ at $37^{\circ} \mathrm{C}$. To terminate the assay, the contents of each tube were centrifuged and aliquot portions of the supernatant solution counted in modified Bray's solution in a Packard Tri-Carb scintillation counter (2). An excess of trypsin $(2 \times$ crystallized, Worthington Biochemical Corp., Freehold, N. J.) was incubated with a collagen gel in each assay to serve as a quality control for the collagen. Viscometry was used to monitor the reaction of enzyme and collagen in solution (approximate concentration of $0.08 \%$ ). Ostwald viscometers were used with the water bath temperature maintained at $27^{\circ}$ $\pm 0.05^{\circ} \mathrm{C}$. The viscometric data were expressed as per cent initial specific viscosity $\left(\eta_{\mathbf{s p}}\right)$ as a function of time.

Analysis of reaction products. Disc electrophoresis on polyacrylamide gels of the products of reaction of enzyme and collagen in solution at $27^{\circ} \mathrm{C}$ was performed according to the method of Nagai, Gross, and Piez (9).

Segment long spacing (SLS) aggregates of tropocollagen (TC) and the products of the reaction with enzyme were produced by the addition of $0.5 \%$ salt-free adenosine triphosphate (ATP) to an equal volume of reaction products in $0.05 \mathrm{M}$ acetic acid containing the equivalent of $0.05-0.1 \%$ collagen (6). Specimens for electron microscopy were prepared in the following manner. A drop of sample was placed on a 400-mesh carbon-coated grid and withdrawn nearly to dryness with a strip of lens paper. In similar fashion a drop of ammonium molybdate ( $1 / 10$ saturated, aqueous) was applied and immediately withdrawn. This procedure, referred to as "negative staining," results in the deposition of an electron-dense glass that surrounds particles of the sample. Grids were examined in a Philips EM-200 electron microscope at an instrumental magnification of 41,500 times. SLS aggregates seen were consistent with aggregates of the intact tropocollagen or TC, $\mathrm{TC}^{\Delta}$ (the long fragment representing the amino terminal $\frac{3}{4}$ of the molecule), and $\mathrm{TC}^{\mathrm{B}}$ (the shorter carboxy terminal $\frac{1}{4}$ fragment). Partially purified samples of $\mathrm{TC}^{\mathrm{B}}$ were obtained by a method of Sakai and Gross (10): $\mathrm{TC}^{\mathbf{\Delta}}$ and unreacted collagen were precipitated at $4^{\circ} \mathrm{C}$ with solid ammonium sulfate (final concentration $18 \%$ ), followed by centrifugation. Further ammonium sulfate was then added to the supernatant solution to bring the concentration of ammonium sulfate to $30 \%$. The precipitate formed was found to contain most of the $\mathrm{TC}^{\mathbf{B}}$ and very little $\mathrm{TC}^{\mathbf{A}}$ as monitored by disc electrophoresis.

Preparation of collagenase. Mass cultures of rheumatoid synovial tissue were prepared as described previously (1-3). Colchicine (USP, Lilly) was added to some media in a final concentration of $0.1 \mu \mathrm{g} / \mathrm{ml}$ to increase the yield of enzyme $(3,11)$. Culture media were centrifuged in a Sorvall refrigerated centrifuge, dialyzed against $0.1 \mathrm{~m}$ Tris- $\mathrm{HCl}, \mathrm{pH} 7.6$, and $0.005 \mathrm{M} \mathrm{CaCl}_{2}$, and concentrated using Aquacide (Calbiochem, Los Angeles, Calif.). Selected, concentrated media were subjected to gel filtration at $4^{\circ} \mathrm{C}$ on columns of Sephadex G-200, G-150, or Bio-Gel P-200 equilibrated with 0.01 M Tris- $\mathrm{HCl}, \mathrm{pH} 7.6,0.2 \mathrm{M} \mathrm{NaCl}$, and $0.005 \mathrm{M} \mathrm{CaCl}_{2}$. Sodium azide $(0.02 \%)$ was added to the buffer to prevent bacterial growth.

Miscellaneous. The inhibition of synovial collagenase by synovial fluid or serum was assayed by incubation of the substance to be tested with partially purified synovial enzyme. Protein determinations on synovial fluids were per- 
formed by the biuret method (12). Hyaluronidase from bovine testis $(465 \mathrm{U} / \mathrm{mg})$ was obtained from Calbiochem. Soybean trypsin inhibitor was obtained from Sigma Chemical Co. Crystallized yeast alcohol dehydrogenase and $\alpha$-chymotrypsin, both used in calibration of a Bio-Gel P-200 column, were assayed by the method of Racker (13) and Kunitz (14), respectively.

\section{RESULTS}

Collagenase activity was found in concentrated culture media from mass cultures of rheumatoid synovium. The enzyme was then partially purified by gel filtration on Sephadex G-200 (Fig. 1). Fractions containing collagenase activity were pooled, concentrated, and used in subsequent experiments. Synovial fluid aspirated from the knee of a patient with degenerative joint disease and centrifuged at $10,000 \mathrm{~g}$ to remove cells and particulate matter inhibited the action of this partially purified synovial collagenase upon reconstituted collagen fibrils at $37^{\circ} \mathrm{C}$ (Table I). When trypsin was incubated with the synovial fluid before enzyme was added, the inhibitory effect of the normal synovial fluid was abolished. Degradation of hyaluronic acid in the synovial fluid by the action of testicular hyaluronidase did not diminish the inhibition. This preparation of hyaluronidase was shown

TABLE I

Effect of Noninflammatory Synovial Fluid on Synovial Collagenase

\begin{tabular}{lcc}
\hline & $\begin{array}{c}\text { Sample minus } \\
\text { control }\end{array}$ & Inhibition \\
\hline Synovial enzyme $(E)$ & $c p m$ & $\%$ \\
$E+$ noninflammatory synovial & 989 & - \\
$\quad$ fluid (NSF) & 21 & 98 \\
$E+$ (NSF + trypsin) & 974 & \\
$E+$ (NSF + hyaluronidase) & 65 & 93 \\
Trypsin & 82 & - \\
\hline
\end{tabular}

The assay system was as follows: $50 \mu \mathrm{l}$ of solutions of ${ }^{14} \mathrm{C}$ collagen $(0.2 \%$, containing $1200 \mathrm{cpm})$ were warmed at $37^{\circ} \mathrm{C}$ to form gels; $50 \mu 1$ of partially purified synovial enzyme (E) (approximately $20 \mu \mathrm{g}$ protein) was added to the appropriate tubes; $50 \mu \mathrm{l}$ from one of the following mixtures and (or) Tris$\mathrm{CaCl}_{2}$ buffer was then added to bring final volume to $200 \mu \mathrm{l}$. $10 \mu \mathrm{l}$ tryspin $(1 \mathrm{mg} / \mathrm{ml})$ was incubated at $37^{\circ} \mathrm{C}$ for $30 \mathrm{~min}$ with $1.0 \mathrm{ml}$ of synovial fluid (NSF) from a patient with a noninflammatory knee effusion; then $10 \mu l$ soybean tryspin inhibitor $(1.0 \mathrm{mg} / \mathrm{ml})$ was added to this mixture to inactivate the tryspin. $10 \mu \mathrm{l}$ hyaluronidase $(1.0 \mathrm{mg} / \mathrm{ml})$ was incubated with $1.0 \mathrm{ml} \mathrm{NSF}$ at $37^{\circ} \mathrm{C}$. All mixtures plus soybean trypsin inhibitor and NSF alone were then dialyzed against $0.1 \mathrm{M}$ Tris- $\mathrm{HCl}, \mathrm{pH} 7.6,0.005 \mathrm{M} \mathrm{CaCl}_{2}$ before incubation with ${ }^{14} \mathrm{C}$-collagen gels and enzyme for $4 \mathrm{hr}$ at $37^{\circ} \mathrm{C}$. When incubated without added collagenase, neither hyaluronidase nor soybean tryspin inhibitor produced collagenolysis.
TABLE II

Variations in Collagenolytic Actirity in Synorial Fluid from One Patient with Rheumatoid Arthritis

\begin{tabular}{ccc}
\hline Date aspirated & cpm released & Synovial fluid \\
\hline $3 / 7 / 68$ & 0 & 18,700 \\
$3 / 21 / 68$ & 278 & 28,000 \\
$3 / 25 / 68$ & 317 & - \\
$4 / 18 / 68$ & 0 & 12,150 \\
\hline
\end{tabular}

Results of the collagenolytic assay and the leukocyte count (WBC $/ \mathrm{mm}^{3}$ ) of synovial fluids aspirated from the same knee of a patient with chronic, progressive rheumatoid arthritis on the date noted are shown. All four assays were performed on the same day using the same collagen gels as substrate. Differential leukocyte counts were similar in all fluids (80$87 \%$ polymorphonuclear leukocytes). Assay system was as follows: $50 \mu \mathrm{l}{ }^{14} \mathrm{C}$-collagen $(0.2 \%$ gels containing $1700 \mathrm{cpm})$; $100 \mu \mathrm{l}$ synovial fluid; $50 \mu \mathrm{l}$ of Tris- $\mathrm{CaCl}_{2}$ buffer; incubation time was $4 \mathrm{hr}$ at $37^{\circ} \mathrm{C}$. Results are corrected for control gel incubated without enzyme.

to be active by its ability to decrease viscosity of the synovial fluid to that of serum of a similar protein concentration. Heating the synovial fluid at $56^{\circ} \mathrm{C}$ for $4 \mathrm{hr}$ did not decrease the inhibitory activity. 42 samples of synovial fluid from patients with a variety of disorders were then assayed using the system described in Table I. Included among these specimens of synovial fluicl were 22 from patients with rheumatoid arthritis. Of the 20 synovial fluids from patients other than those with rheumatoid arthritis, 15 inhibited synovial collagenase more than $76 \%$. All seven fluids from patients with traumatic or degenerative arthritis were in this category. Fluids that showed less than $76 \%$ inhibition were from patients with septic arthritis (three of five), gout (one of two), and pseudogout (one of three). In contrast, 13 of the 22 fluids from patients with active rheumatoid arthritis showed inhibition less than $76 \%$. Differences in inhibition could not be correlated with concentration of protein in the fluids.

TABLE III

Variations in Collagenase Activity and Inhibitory Capacity of Synorial Fluid from One Patient

\begin{tabular}{cccc}
\hline Sample & Date aspirated & Inhibition & Collagenolysis \\
\hline & & $\%$ & $\%$ \\
(a) & $11 / 22 / 67$ & 61 & 10 \\
(b) & $4 / 17 / 68$ & 95 & 5 \\
(c) & $9 / 20 / 68$ & 37 & 46 \\
\hline
\end{tabular}

Synovial fluid was aspirated from the same knee of a patient with rheumatoid arthritis on the dates shown. Leukocyte count ranged from $13,000-29,000 / \mathrm{mm}^{3}$ in these fluids. Assay system was that described in Tables I and II. 
Of particular interest were five other synovial fluid specimens which inhibited synovial enzyme less than $10 \%$. Two of these were from presumed septic joints (cultures negative in a clinical setting consistent with gonococcal arthritis) and three from rheumatoid joints. When samples of these fluids were incubated without added enzyme, significant collagenolytic activity was noted in each specimen. These observations led us to study synovial fluid from individual patients aspirated at intervals of weeks to months to compare the degree of inhibition and (or) collagenase at one phase of disease with another. In Table II are shown the results of such a study in one patient with chronic, seropositive rheumatoid arthritis. The synovial fluid was found to have collagenolytic activity during one 2 -wk period. There was no measurable collagenase in fluids aspirated before or after this period.

There was no correlation between synovial fluid leukocyte count and collagenase activity in the many synovial fluids studied. Several fluids with more than 60,000 $\mathrm{WBC} / \mathrm{mm}^{3}$ and differential counts of $>90 \%$ polymorphonuclear leukocytes were demonstrated to have no significant enzyme activity. Freezing and thawing synovial fluids had no measurable effect upon collagenase activity; once the enzyme had been partially purified, however, the activity diminished rapidly on storage.

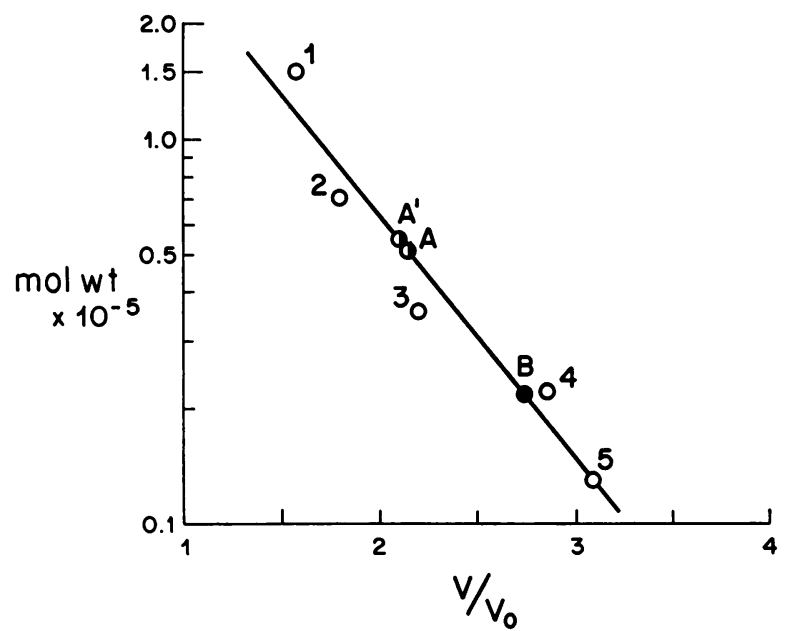

FIGURE 2 Determination of approximate molecular weights of collagenases by gel filtration. Open circles represent proteins used for calibration of the column: $1=$ alcohol dehydrogenase, mol wt 150,$000 ; 2=$ bovine serum albumin, mol wt 70,$000 ; 3=$ pepsin, mol wt 35,$500 ; 4=\alpha$-chymotrypsin, mol wt 22,$500 ; 5=$ cytochrome $C$, mol wt 13,000 . The half-closed circle labeled " $A$ " and closed circle "B" indicate the values for $V / V_{0}$ obtained for the two collagenases found in synovial fluid from the same patient. Halfclosed circle " $\mathrm{A}$ " "indicates the value $\mathrm{V} / \mathrm{V}_{0}$ for the collagenase from the synovial fluid from another rheumatoid patient in which there was no enzyme corresponding to enzyme "B."

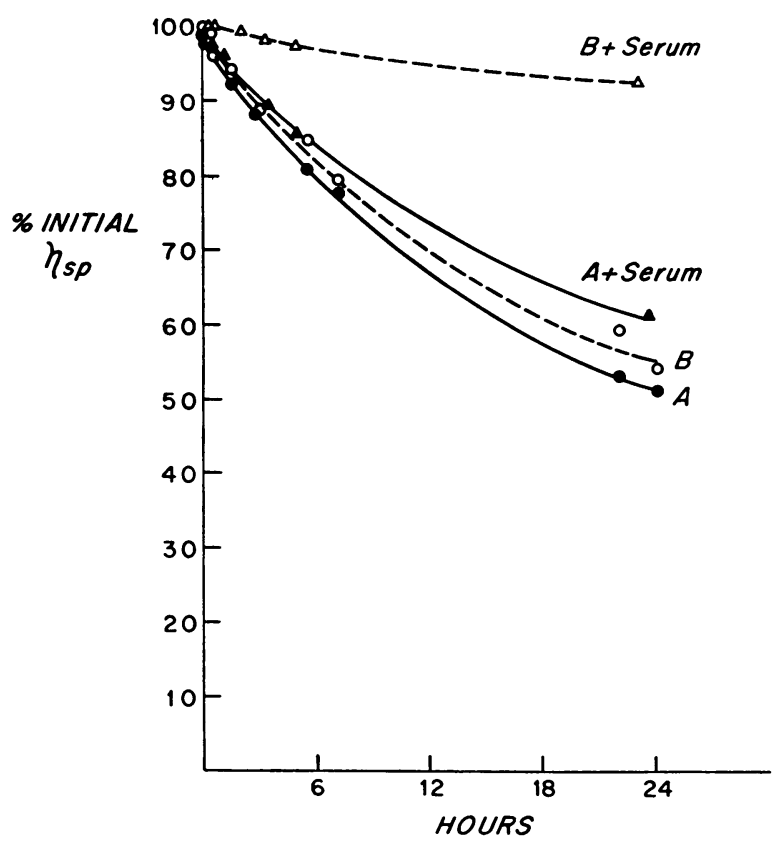

FIGURE 3 Effect of serum on synovial fluid collagenases as measured viscometrically. Reaction mixtures consisted of 40 $\mu 1$ enzyme solution, $200 \mu 10.4 \%$ salt-soluble guinea pig skin collagen, and $0.1 \mathrm{M}$ Tris- $\mathrm{HCl}, \mathrm{pH} 7.6,0.005 \mathrm{M} \mathrm{CaCl}_{2}, 0.2 \mathrm{M}$ $\mathrm{NaCl}$ to give a final volume of $1.0 \mathrm{ml} .100 \mu 1$ pooled normal human serum was added in place of $100 \mu \mathrm{l}$ buffer where indicated. After $24 \mathrm{hr}, 10 \mu \mathrm{l}$ EDTA, $0.5 \mathrm{~m}$, was added to stop the reaction. " $A$ " refers to the first enzyme peak eluted from a Bio-Gel P-200 column, "B" to the second enzyme (see Fig. 2).

Synovial fluid from another patient with rheumatoid arthritis was also demonstrated to lyse fibrils of collagen. However, when similar amounts of this sample of synovial fluid were incubated with partially purified synovial enzyme and a collagen gel, the collagenolytic effect was not additive. On the contrary, the activity of the added synovial enzyme was partially inhibited by this sample of synovial fluid. Fluid aspirated from the knee joint on three separate occasions showed variable endogenous collagenolytic activity as well as variable inhibition of partially purified synovial collagenase added to it (Table III). However, the fluid which had the least collagenolytic activity was most inhibitory and the fluid which inhibited the least had the highest collagenolytic activity. There are several possible ways to interpret these data, among which are the following: (a) that an easily reversible association existed between synovial fluid inhibitor proteins and collagenase, and that in these particular patients there was a decreased concentration of this inhibitor protein; $(b)$ that a part of the collagenase present in the synovial fluid was not inhibited by other proteins present in the fluid; and $(c)$ that a combination of $(a)$ and $(b)$ was operative. 
Alternative $(a)$ has not been proven or disproven. We have not yet isolated a specific inhibitory protein from synovial fluid or serum. To examine alternative (b) it was necessary to purify partially the collagenase in synovial fluid and compare it with collagenase obtained from culture of rheumatoid synovium in vitro. A synovial fluid $(20 \mathrm{ml})$ with collagenolytic activity (sample c, Table III) was incubated for $4 \mathrm{hr}$ at room temperature with $25 \mu \mathrm{g}$ of hyaluronidase. The mixture was then dialyzed against $0.1 \mathrm{M}$ Tris- $\mathrm{HCl}, \mathrm{pH}$ 7.6, $0.005 \mathrm{M} \mathrm{CaCl}_{2}$ and concentrated within dialysis membranes by immersion of the sacs in dry Aquacide. An equivalent amount of fluid from the knee of a patient with degenerative joint disease was prepared in the same manner. Both concentrated fluids were applied in turn to a column of Sephadex G-150 $(60 \times 2.5 \mathrm{~cm})$ equilibrated with $0.01 \mathrm{~m}$ Tris- $\mathrm{HCl}, \mathrm{pH} 7.6,0.005 \mathrm{M} \mathrm{CaCl}_{2}$ containing $0.2 \mathrm{M} \mathrm{NaCl}$. Assay of the eluate from the column to which the sample of rheumatoid fluid had been applied revealed a broad peak of collagenase activity which began to appear shortly after the void volume of the column had been collected. No collagenase was detectable in eluates from the column containing the specimen from degenerative arthritis. The fractions containing collagenase were pooled, concentrated, and passed through a column of Sephadex G-200 $(60 \times 0.9 \mathrm{~cm})$ equilibrated with the same buffer.

Assays for collagenase revealed two distinct peaks of activity in eluates from the G-200 column. One of these was eluated in a position similar to that of the cultured synovial enzyme shown in Fig. 1. The other was less retarded and presumably of greater molecular weight. Fractions containing these two activities were concentrated with Aquacide and passed through a BioGel P-200 column $(112 \times 0.9 \mathrm{~cm})$ which had been calibrated using globular proteins of known molecular weight (15) (Fig. 2). The void volume ( $\left.\mathrm{V}_{0}\right)$ was established using Blue Dextran (Pharmacia Fine Chemicals). $\mathrm{V} / \mathrm{V}_{0}$ for the smaller of these two enzymes ("B") was in the range found for partially purified synovial

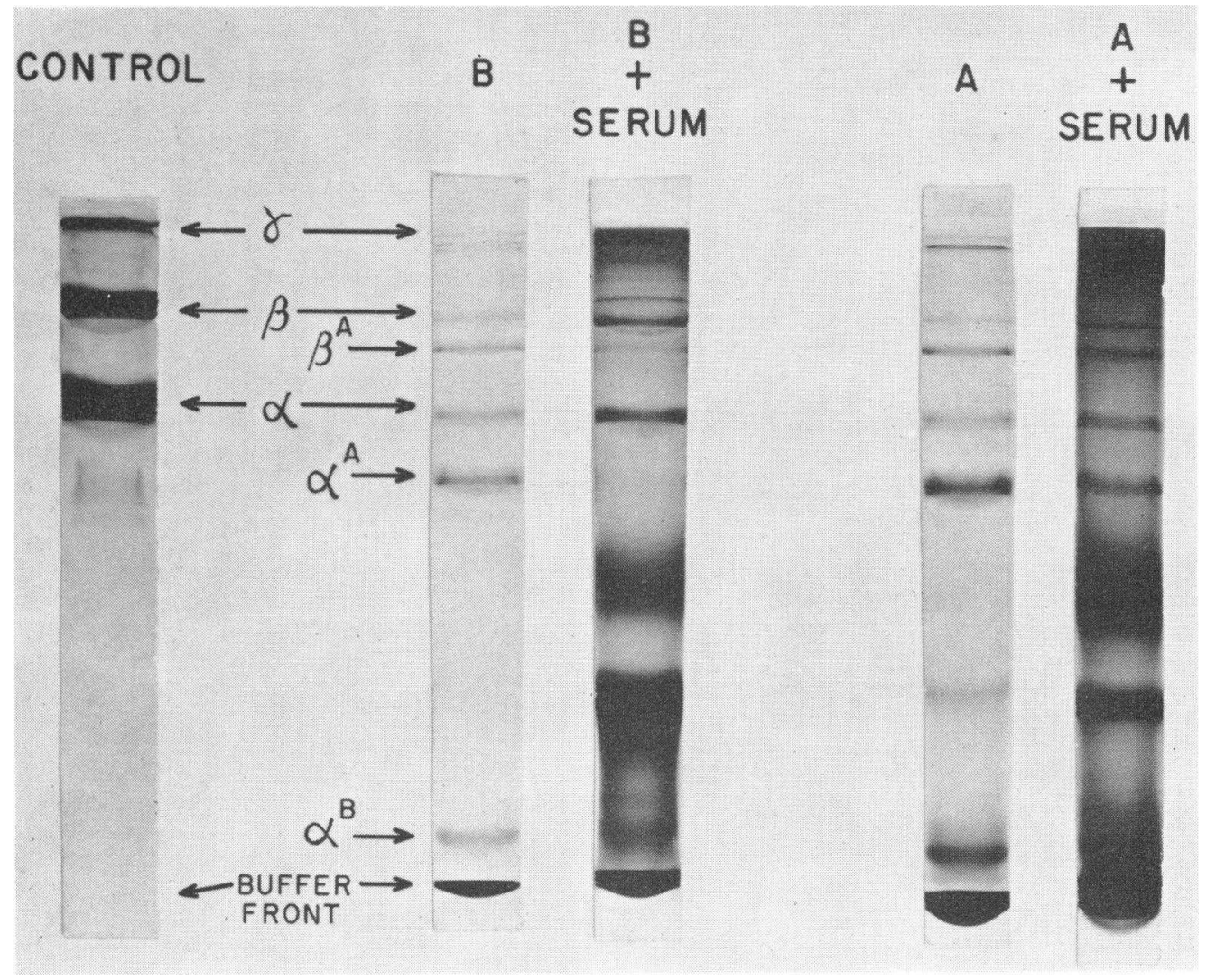

FIGURE 4 Disc electrophoresis of reaction products of synovial fluid collagenases. $100 \mu 1$ samples of each reaction mixture described in Fig. 3 were subjected to disc electrophoresis on polyacrylamide gels. The control sample contained five times more collagen than did the gels of the reaction products. Definitions for the symbols used are as follows: $\alpha=$ single polypeptide chain; $\beta=$ a dimer of $\alpha$-chains, linked covalently; $\gamma=$ three-stranded polypeptide chain $; \beta^{\mathbf{A}}$ and $\alpha^{\mathbf{A}}=\mathrm{TC}^{\mathbf{A}} ; \alpha^{\mathrm{B}}=\mathrm{TC}^{\mathrm{B}}$. 
collagenase and $\alpha$-chymotrypsin. Its molecular weight was estimated to be 20,000 to 25,000 . The other collagenolytic activity ("A") was less retarded and its estimated molecular weight was roughly twice that of collagenase "B."

Four rheumatoid synovial fluids containing collagenolytic activity were found in a separate group of 27 fluids from patients with rheumatoid arthritis. This activity was assayed with and without the addition of pooled normal human serum, using the ${ }^{14} \mathrm{C}$-collagen fibril assay at $37^{\circ} \mathrm{C}$ as described in Tables I and II. It was found that $10 \mu \mathrm{l}$ of serum inhibited the total collagenolytic activity in these four fluids by $0 \%, 37 \%, 46 \%$, and $24 \%$, whereas $5 \mu \mathrm{l}$ of serum was sufficient to inhibit the partially purified synovial collagenase more than $80 \%$. These results suggested that the collagenase which was not inhibited by serum probably accounted for most of the total activity in these fluids. The observation that some inhibition resulted from the addition of serum to three of four of these fluids indicated that the enzyme resembling cultured synovial collagenase (" $B$ ") accounted for a definite fraction of the total collagenase activity in spite of the presence of other, possibly inhibitory, synovial fluid proteins. The one synovial fluid in which collagenase was not inhibited by proteins was dialyzed and concentrated to $1.0 \mathrm{ml}$ after incubation for $30 \mathrm{~min}$ at $37^{\circ} \mathrm{C}$ with $10 \mu \mathrm{g}$ hyaluronidase, and passed over the Bio-Gel P-200 column. Only one peak containing collagenolytic activity was found; the peak is labeled $\mathrm{A}^{\prime}$ in Fig. 2. As expected, this activity was eluted in a position similar to the enzyme which was not inhibited by serum.

Activities of the two enzymes " $\mathrm{A}$ " and " $\mathrm{B}$ " were assayed using collagen in solution at $27^{\circ} \mathrm{C}$ with and without added serum and following the reaction viscometrically (Fig. 3). It can be seen that the activity of "B" with an estimated molecular weight similar to synovial collagenase was markedly inhibited by normal human serum added in a final dilution of $1: 10$. The other collagenase activity ("A") was not inhibited significantly by the same concentration of serum. At the end of 24 $\mathrm{hr}$ incubation at $27^{\circ} \mathrm{C}$, the reaction was stopped by the addition of ethylenediaminetetraacetate (EDTA) and the reaction products were subjected to electrophoresis on polyacrylamide gels (Fig. 4). The band pattern confirmed the viscometric findings: enzyme " $A$ " cleaved the collagen molecule in the presence of serum producing a pattern consistent with $\mathrm{TC}^{\mathbf{A}}$ and $\mathrm{TC}^{\mathrm{B}}$, whereas enzyme " $\mathrm{B}$ " was inhibited.

In Table IV the effects of synovial collagenases on collagen in solution and collagen as fibrils are compared. The ratio of the rate at $37^{\circ} \mathrm{C}$ to that at $27^{\circ} \mathrm{C}$ indicates that in partially purified form the synovial fluid enzyme "A" degraded fibrils as effectively as did both crude and
TABLE IV

Comparative Lysis by Synovial and Synovial Fluid Collagenases at $27^{\circ} \mathrm{C}$ (Collagen in Solution) and $37^{\circ} \mathrm{C}$ (Fibril Assay)

\begin{tabular}{lcc}
\hline & $27^{\circ} \mathrm{C}$ & $37^{\circ} \mathrm{C}, \%$ total \\
\hline & $U / h r$ & $c p m / h r$ \\
Synovial fluid enzyme "A" & 6.0 & 6.1 \\
$\begin{array}{l}\text { Synovial collagenase } \\
\quad \text { (partially purified) }\end{array}$ & 7.2 & 4.4 \\
$\begin{array}{l}\text { Synovial collagenase } \\
\text { (crude) }\end{array}$ & 23.1 & 21.6 \\
\hline
\end{tabular}

Equal amounts of each collagenase preparation were used in both the assay at $37^{\circ} \mathrm{C}$ with ${ }^{14} \mathrm{C}$-labeled collagen fibrils as substrate and in the assays at $27^{\circ} \mathrm{C}$ with collagen in solution as substrate. Rates for the viscometric assays were determined from the initial slopes of the fall in specific viscosity when plotted as a semilogarithmic function of time of incubation (16) and_are_expressed in arbitrary units (U/hr)

partially purified synovial collagenase obtained from culture of rheumatoid synovium in vitro.

Both collagenases ("A" and "B") from synovial fluid and the cultured synovial collagenase produced SLS aggregates consistent with the same site of cleavage of collagen molecules. Moreover, since SLS of both TC and $\mathrm{TC}^{\mathrm{B}}$ were identified, the molecules had to be cleaved across the three chains and not digested simply from the $B$ end.

In Figs. 5 and 6 the results of "negative staining" of SLS aggregates are shown. To visualize adequately the $\mathrm{TC}^{\mathrm{B}}$ SLS it was found necessary to precipitate these fragments with ammonium sulfate and then aggregate the $\mathrm{TC}^{\mathrm{B}}$ from a relatively homogeneous preparation of these smaller fragments. A great tendency for hybrid forms of SLS to develop was found, particularly in reaction mixtures in which the enzyme had been allowed to take the reaction to completion. Although it was difficult to form individual SLS of $\mathrm{TC}^{\mathrm{B}}$ large enough to show banding patterns, polymers of $\mathrm{TC}^{\mathrm{B}}$ SLS were occasionally found (Fig. $6 a$ ). Fig. $6 b, c$, and $d$ show other evidence for the presence of intact $\mathrm{TC}^{\mathrm{B}}$. Measurements of the SLS suggest that the enzyme has not cleaved further either the $\mathrm{TC}^{\mathrm{B}}$ or $\mathrm{TC}^{\mathrm{A}}$ fragment under these conditions.

\section{DISCUSSION}

These data indicate that collagenase is produced and released from cells in vivo in man, and that its production is not demonstrable only by culturing certain epithelial and mesenchymal cells in vitro. With the exception of the collagenase extracted from homogenates of human leukocytes $(7,8)$, previous demonstrations of collagenases from vertebrate tissues required that the tissues 
be cultured in vitro on collagen gels or in enriched media. This has been a requirement for demonstrating and harvesting the rheumatoid synovial collagenase, and has served as an objection to assigning to rheumatoid synovial collagenase a significant role in the destruction of connective tissue accompanying this disease.
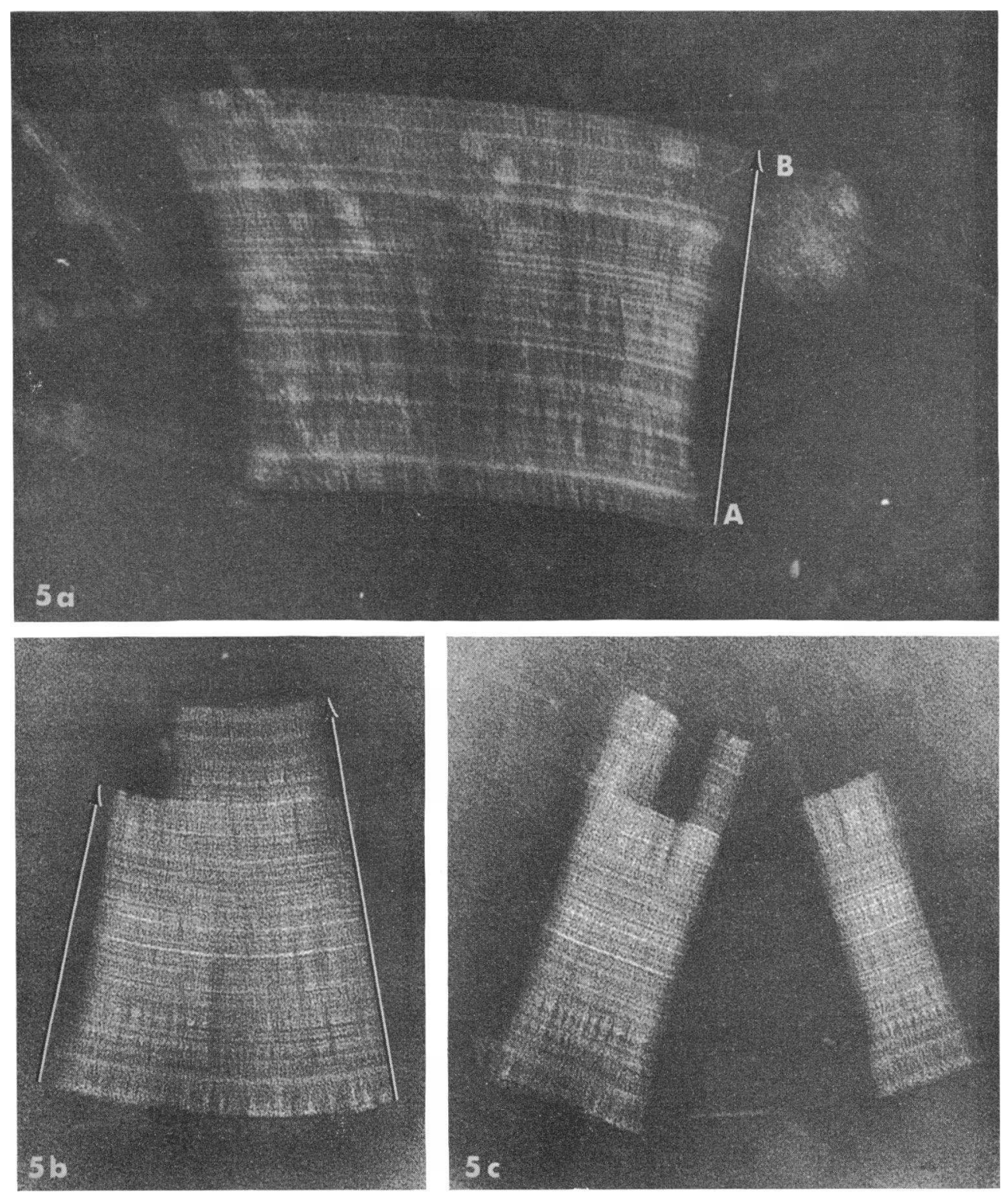

FigURE 5 Flectron microscopy of reaction products of synovial fluid collagenases. (a). Control preparation of TC SLS (no enzymatic cleavage of tropocollagen monomers). This and all subsequent figures are the result of negative staining with ammonium molybdate. The arrow parallel to the long axis of the TC monomers runs from the $A$ ( $N$-terminus) to the $B$ (C-terminus) end of the molecule. This convention is used wherever the banding pattern is displayed well enough to permit a directional designation. The use of $\mathrm{A}$ and $\mathrm{B}$ to designate specific ends of the molecule is according to the nomenclature proposed by Hodge and Schmitt (17). However, the direction of the arrows has been reversed consistent with the conventional reading of proteins from the $\mathrm{N}$-terminal end. The length of $\mathrm{TC}$ as measured by this method is very nearly $3000 \mathrm{~A}$. $(b)$ and $(c)$. Hybrid forms of TC and TC ${ }^{\mathbf{\Delta}}$ SLS. SLS aggregates of undegraded and enzymatically digested TC illustrate that the point of cleavage is almost exactly $750 \mathrm{~A}$ or $25 \%$ of the distance from the B end of the molecule. The short ( $\mathrm{TC}^{\mathrm{B}}$ ) fragments do not display this tendency to hybridize with TC aggregates. $\times 175,000$. 
We have reported elsewhere (3) that collagenase is produced in vitro by synovial tissue from degenerative joint disease as well as by synovium from nonrheumatoid, inflammatory joint disease although most samples from degenerative joint disease yield no detectable en- zyme and when enzyme is produced the amounts are extremely small compared to rheumatoid tissue. Nevertheless, there must be factors involved in resorption of collagen in rheumatoid disease other than simply the capacity of the tissue to elaborate a collagenase. This is

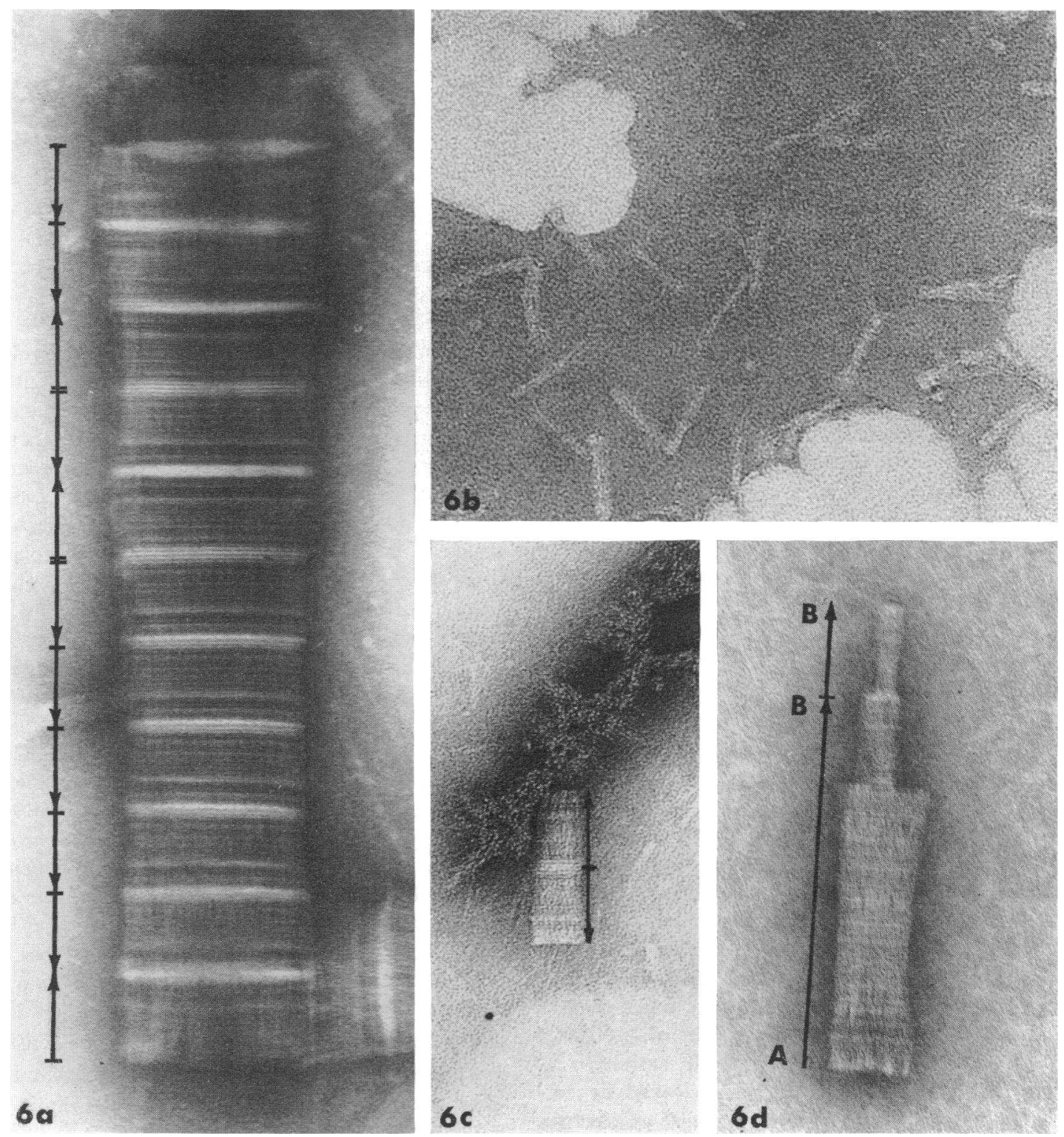

FigtRE 6 Electron microscopy of reaction products of synovial fluid collagenases. (a) Polymer of $\mathrm{TC}^{\mathrm{B}} \mathrm{SLS}$. This elongated structure shows $\mathrm{TC}^{\mathbf{B}}$ aggregates in apposition with each other in all three of the possible end-to-end associations. The direction of the arrows is according to the scheme described in the legend to Fig. 5. There is strong suggestion that there is no overlap in any of the associations since measurements everywhere along this structure provide multiples of 750 A. $(b)$ Individual SLS of $\mathrm{TC}^{\mathrm{B}}$. The failure to form wide SLS aggregates by the $\mathrm{TC}^{\mathbf{B}}$ preparation makes definition of banding pattern difficult; length of $\mathrm{TC}^{\mathbf{B}}$, where it can be measured, is $750 \mathrm{~A}$. (c) Dimeric form of $\mathrm{TC}^{\mathbf{B}}$ SLS. Banding of this structure permits its identification as a B-end to B-end dimer. $(d)$ Hybrid of TC and TC ${ }^{\mathbf{A}}$ SLS with appended $\mathrm{TC}^{\mathrm{B}} \mathrm{SLS}$ in an A-end to B-end association. $\times 175,000$. 
emphasized by our finding that synovial fluid obtained from noninflammatory synovitis inhibits the action of synovial collagenase upon collagen fibrils at $37^{\circ} \mathrm{C}$. To mediate collagenolysis in rheumatoid arthritis the collagenase must gain access to its substrate without being inactivated by this inhibitory protein(s) in serum or synovial fluid. It was observed that, in general, the rheumatoid synovial fluids contained less apparent inhibitor per unit protein than did degenerative or nonrheumatoid inflammatory fluids. We have not ruled out the possibilities that there is actually less inhibitory protein present in rheumatoid synovial fluid or that the inhibitory proteins have been altered, for example by proteolysis, and have become less effective. However, the possibility supported by the data presented here is that at least two collagenases are elaborated. One of these is not inhibited by serum or synovial fluid proteins whereas the second is inhibited by these proteins and has other characteristics similar to those of the enzyme obtained from culture in vitro.

The finding of two distinct collagenolytic activities in synovial fluid has raised the question of whether these activities are related or whether they represent different enzymes produced and released by different cells. Our initial estimates have indicated that the molecular weights differ by a factor of two, suggesting that these enzymes may be related as a monomer to a dimer. It is also conceivable that the enzymes are unrelated. The enzyme from polymorphonuclear leukocytes $(8,18)$ is resistant to serum inhibition, has a higher apparent molecular weight $(70,000)$ than the cultured synovial enzyme, and properties similar to those of synovial fluid collagenase "A." However, one difference between the action of collagenase " $A$ " and the leukocytic collagenase is the ability to digest collagen fibrils at $37^{\circ} \mathrm{C}$. It is reported that the partially purified leukocytic collagenase is relatively ineffective in degrading reconstituted collagen fibrils when compared with its activity upon collagen in solution $(8,18)$. In contrast, enzyme "A" from synovial fluid degrades fibrils and molecules in solution in a ratio similar to that found using partially purified synovial collagenase. In addition, we have found several synovial fluids with white blood cell counts of $>60,000 /$ $\mathrm{mm}^{3}$ which have negligible collagenolytic activity.

The demonstration of the fragments cleaved by collagenase by disc-gel electrophoresis as well as electron microscopy of the SLS indicate that both enzymes in synovial fluid cleave the collagen molecule in the same region that other vertebrate and amphibian collagenases do. However, until the amino acids at the sites of cleavage are identified, no claim of identity of action of one enzyme to the other can be made.

It should be noted that in many preparations of SLS using the crude reaction products, many $\mathrm{TC}^{\boldsymbol{A}}$ SLS ag- gregates could be demonstrated but few $\mathrm{TC}^{\mathbf{B}}$ were seen. This could mean that either the smaller $\mathrm{TC}^{\mathbf{B}}$ had been degraded further or, for some technical reason, could not easily be demonstrated. Present evidence favors the latter interpretataion. After differential precipitation of $\mathrm{TC}^{\mathbf{A}}$ away from $\mathrm{TC}^{\mathbf{B}}$ by use of ammonium sulfate, the smaller fragments were demonstrable in large numbers when the same techniques were used to precipitate the SLS and stain the grids. Some comments are pertinent regarding the use of "negative staining" techniques to demonstrate SLS aggregates of products of cleavage by collagenase. The sharpness of the ends of the molecules permitted us to calculate length more accurately than with "positive staining." The presence of hybrids of TC and $\mathrm{TC}^{\boldsymbol{A}}$ and even of $\mathrm{TC}, \mathrm{TC}^{\boldsymbol{A}}$ and $\mathrm{TC}^{\mathbf{B}}$ enabled us to demonstrate clearly where the point of cleavage by the enzymes occurred.

Since two collagenolytic activities have been found in synovial fluid, both may have significant roles in the destruction of collagen in vivo. The small enzyme might be of importance at the sites where the rheumatoid pannus is in direct contact with cartilage and other collagenous structures. This area would be most remote from vascular supply and might be expected to have the lowest concentration of inhibitory proteins derived from serum. The larger enzyme could act at any place in the joint since its activity is unaffected by high concentrations of serum proteins. It should be mentioned that serum proteins do not prevent production and relase of collagenase by cultured synovium although the $a c$ tivity of the collagenase is inhibited (Harris and Krane, unpublished observations).

It has been demonstrated by Curtiss and Klein (19) that in order to destroy articular cartilage, the collagen must be broken down. In their experiments the structural integrity of cartilage was not disturbed when the proteinpolysaccharides were degraded with papain. However, bacterial collagenase readily destroyed cartilage. The synovial fluid in an inflamed knee may contain collagenases as we have shown as well as other enzymes capable of degrading constituents of cartilage other than collagen. We have demonstrated that in an individual patient, collagenase cannot always be demonstrated in synovial fluid. This is perhaps why other investigators were unable to find collagenase in rheumatoid synovial fluid (20). It remains to be determined whether the amount of collagenase in a given synovial fluid can be correlated with the rate of articular destruction or the clinical activity of the disease.

\section{ACKNOWLEDGMENTS}

We are grateful to Miss Linda Ferzoco for valuable technical assistance, to Doctor Jerome Gross for helpful advice, and to the orthopedic surgeons who have provided us with rheu- 
matoid synovium, particularly Doctors Theodore Potter and William Thomas.

This work was supported by grants AM 3564, HE 06664, and Training Grant AM 5067 of the U. S. Public Health Service, and by grants from the Massachusetts Arthritis Foundation and the John A. Hartford Foundation, Inc.

\section{REFERENCES}

1. Evanson, J. M., J. J. Jeffrey, and S. M. Krane. 1967. Human collagenase: identification and characterization of an enzyme from rheumatoid synovium in culture. Science (Washington). 158: 499.

2. Evanson, J. M., J. J. Jeffrey, and S. M. Krane. 1968. Studies on collagenase from rheumatoid synovium in tissue culture. J. Clin. Invest. 47: 2639.

3. Harris, E. D., Jr., G. L. Cohen, and S. M. Krane. 1969. Synovial collagenase: its presence in culture from joint disease of diverse etiology. Arthritis Rheum. 12: 92.

4. Lazarus, G. S., J. L. Decker, C. H. Oliver, J. R. Daniels, C. V. Multz, and H. M. Fullmer. 1968. Collagenolytic activity of synovium in rheumatoid arthritis. N. Engl. J. Med. 279: 914.

5. Eisen, A. Z., J. J. Jeffrey, and J. Gross. 1968. Human skin collagenase. Isolation and mechanism of attack on the collagen molecule. Biochim. Biophys. Acta. 151: 637.

6. Gross, J., and Y. Nagai. 1965. Specific degradation of the collagen molecule by tadpole collagenolytic enzyme. Proc. Nat. Acad. Sci. U. S. 54: 1197.

7. Lazarus, G. S., R. S. Brown, J. R. Daniels, and H M. Fullmer. 1968. Human granulocyte collagenase. Science (Washington). 159: 1483.

8. Lazarus, G. S., J. R. Daniels, R. S. Brown, H. A. Bladen, and H. M. Fullmer. 1968. Degradation of collagen by a human granulocyte collagenolytic system J. Clin. Invest. 47: 2622

9. Nagai. Y., J. Gross, and K. A. Piez. 1964. Disc electro- phoresis of collagen components. Ann. N. Y. Acad. Sci. 121: 494.

10. Sakai, T., and J. Gross. 1967. Some properties of the products of reaction of tadpole collagenase with collagen. Biochemistry. 6: 518.

11. Harris, E. D., Jr., J. M. Evansón, and S. M. Krane. 1968. Stimulation by colchicine of collagenase production by rheumatoid synovium in culture. J. Clin. Invest. 47 : 45a. (Abstr.)

12. Layne, E. 1957. Spectrophotometric and turbidimetric methods for measuring proteins. III. Biuret method. In Methods of Enzymology. S. P. Colowick and N. O. Kaplan, editors. Academic Press Inc., New York. 450.

13. Racker, E. 1950. Crystalline alcohol dehydrogenase from bakers' yeast. J. Biol. Chem. 184: 313.

14. Kunitz, M. 1947. Crystalline soybean trypsin inhibitor. J. Gen. Physiol. 30: 291.

15. Whitaker, J. R. 1963. Determination of molecular weights of proteins by gel filtration of Sephadex. Anal. Chem. 35: 1950.

16. Gallop, P. M., S. Seifter, and E. Meilman. 1957. Studies on collagen. I. The partial purification, assay, and mode of activation of bacterial collagenase. J. Biol. Chem. 227: 891.

17. Hodge, A. J., and F. O. Schmitt. 1960. The charge profile of the tropocollagen macromolecule and the packing arrangement in native-type collagen fibrils. Proc. Nat. Acad. Sci. U. S. 46: 186.

18. Daniels, J. R., J. Lian, and G. Lazarus. 1969. Polymorphonuclear leukocyte collagenase: isolation and kinetic characterization. Clin. Res. 17: 154. (Abstr.)

19. Curtiss, P. H., and L. Klein. 1963. Destruction of articular cartilage in septic arthritis. J. Bone Joint Surg. A. Amer. Vol. 45 : 797.

20. Dresner, E., A. Kang, and P. Trombly. 1962. The differential hydrolysis of soluble and insoluble collagens by collagenolytic enzyme systems. Arthritis Rheum. 5: 291. (Abstr.) 